\title{
Geochemistry of ground water the Yurubcheno- Tokhomo hydrocarbon accumulation zone
}

\author{
Nikolay Trifonov ${ }^{1,2, *}$ \\ ${ }^{1}$ Tomsk Branch of the Trofimuk Institute of Petroleum-Gas Geology and Geophysics of Siberian \\ Branch of Russian Academy of Sciences, 634055 Tomsk, Russia \\ ${ }^{2}$ National Research Tomsk Polytechnic University, 634050 Tomsk, Russia
}

\begin{abstract}
In this study the chemical analysis of groundwater in Yurubcheno-Tokhomo hydrocarbon accumulation zone (YTHAZ) was carried out. The analysis revealed that fresh, brackish, saline waters and brines of various chemical types occur in the study area. Water salinity increases with the depth, but this dependency is not observed in Vendian and Riphean oil and gas deposits. The most mineralized brines occur in the salt-bearing hydrogeological formation. On the basis of the data on the geochemistry of groundwater, the possibilities of their further practical application were determined.
\end{abstract}

\section{Introduction}

In accordance with hydrogeological zoning, Yurubcheno-Tokhomskaya area is situated within second-order Kamo-Vel'minskii Artesian Basin in the southwestern part of Tungusskii Artesian Basin, East-Siberian Artesian Province [1].

For many years the scientists, among whom were N.I. Tolstihin, E.V. Pinnecker, M.G. Valyashko, I.K. Zaitsev, E.A. Baskov, V.I. Vozhov, A.A. Dziuba, S.L. Shvartsev, M.B. Bukaty, A.E. Kontorovich, S.V. Alekseev, L.P. Alekseeva, A.I. Surnin, V.A. Zuev, Yu.I. Kustov, A.K. Bitner, A.D. Nazarov and others [2-4], have been carrying out the study of the chemical analysis of groundwater and brines of the Tunguska artesian basin. Despite the long-term experience to study the hydrogeochemistry of brines in the region, additional research is highly relevant due to intensification of the exploration and production work in the studied area.

Economic development in the region has already required or will lead to the need to address the issues of water supply with both drinking and process water; high volumes of produced and waste water drainage; and future-oriented enough, but still underdeveloped field of integrated use of brines as a source of hydromineral raw materials $[5,6]$.

\section{Materials and methods}

The subject of scientific research is groundwater saturating the geological section in the YTHAZ.

\footnotetext{
*Corresponding author: Trifonovnik@ mail.ru
} 
The main source of data for the study was the geological and hydrogeological database of the Tomsk Division of Trofimuk Institute of Petroleum-Gas Geology and Geophysics of the Siberian Branch of the RAS, Siberian Platform, which contains study materials conducted in this region since the 50s of the last century.

The chemical analysis was based on the processing of more than 100 groundwater samples. Unfortunately, the problem of the quality of the materials obtained, which is serious enough for this region, does not always allow us to objectively estimate the factual composition of the waters. Therefore, some of the samples were previously rejected.

When rejection, apart from strong indication of poor results of the analysis performed or lack of data of important elements, the following dependencies were used such as: the inverse ratio of the content of calcium ions and sulfate ion in brines or, conversely, the direct dependence of the content of calcium and strontium ions. The analysis results of the samples corresponding to the points "stood out" from the general dependences were checked more precisely, and then the decision was made to use them for further calculations.

The classification of S.L. Shvartsev was used to divide groundwater according to total salinity and $\mathrm{pH}$, and to classify into chemical types according to which the water type was named after the leading anions and cations, with the content of which to exceed $25 \%$-eq. However, those anions and cations take the first place in names whose number prevails in the water.

\section{Results and discussion}

Hydrogeological conditions monitoring the distribution and quality of groundwater remain poorly studied, especially in the upper part of the section, where there is sporadic permafrost area along with thawed rocks. All studied waters occur in terrigenous, carbonate-salt-bearing or carbonate sediments, including numerous trap intrusions. Saltbearing sections contain large horizons of halite and anhydrite deposits. In structural plan, the research area is located within one of the largest structures of the Siberian platform, the Baikitskaya anteclise.

The study of the dependences of the positional distribution of groundwater over the area and in the vertical section is basic to deal with various issues of their practical development and use. In our work we focus on the scheme of the geohydrological stratification of the western regions of the Siberian Platform developed by M.B. Bukaty [2]. In the section of the sedimentary cover 12 aquifer systems are distinguished according to the proposed scheme. Aquifer systems and their horizons are combined into three hydrogeological formations (top-down): suprasalt (paleogene-neogene-quaternary sediments, Triassic, Ordovician middle and upper Cambrian), salt-bearing (middle-lower Cambrian) and subsalt (Cambrian base, Vendian, Riphean).

The salinity and chemical composition of the groundwater of the suprasalt hydrogeological formation mainly depends on the permafrost conditions, the intensity of water exchange and the upward migration from the underlying water-bearing horizon.

The aquifer systems of the suprasalt hydrogeological formation contain fresh infiltration waters in the upper part of the section replaced by salty waters and brines in the lower part of the formation, which is associated with the salinity of underlying Lower Cambrian deposits, as well as by the former halitization and recent gypsum of the Middle Upper Cambrian sediments.

Freshwaters of hydro-carbonate composition mixed according to cations occur, as a rule, at depths down to 160-200 $\mathrm{m}$ with neutral $\mathrm{pH}$ of water (Table). 
Table. The chemical composition of groundwater in Yurubcheno-Tohomskaya hydrocarbon accumulation zone

\begin{tabular}{|c|c|c|c|c|c|c|c|c|c|c|c|c|c|c|}
\hline \multirow[b]{2}{*}{ Index of well } & \multirow{2}{*}{$\begin{array}{l}\text { Sampling } \\
\text { depth, m }\end{array}$} & \multirow[b]{2}{*}{$\begin{array}{l}\text { M, } \\
\text { g/L }\end{array}$} & \multirow[b]{2}{*}{$\mathbf{p H}$} & \multicolumn{11}{|c|}{ Concentration, $\mathrm{g} / \mathrm{L}$} \\
\hline & & & & $\mathrm{Na}^{+}$ & $\mathbf{K}^{+}$ & $\mathrm{Ca}^{2+}$ & $\mathrm{Mg}^{2+}$ & $\mathrm{Cl}^{-}$ & $\mathrm{SO}_{4}{ }^{2-}$ & $\mathrm{HCO}_{3}{ }^{-}$ & $\mathrm{Br}^{-}$ & $\mathrm{Sr}^{2+}$ & $\mathbf{L i}^{+}$ & $\begin{array}{c}\text { Water } \\
\text { type }\end{array}$ \\
\hline \multicolumn{15}{|c|}{ Suprasalt hydrogeological formation } \\
\hline P. Tung. & from spring & 0,06 & 9,2 & 0,008 & 0,001 & 0,01 & 0 & 0,006 & 0 & 0,04 & 0 & - & 0 & $\mathrm{HCO}_{3}-\mathrm{Ca}-\mathrm{Na}$ \\
\hline $\mathrm{Km}-229_{\mathrm{B}}$ & 20 & 0,2 & 7,2 & 0,003 & 0,001 & 0,03 & 0,02 & 0,01 & 0,01 & 0,15 & - & 0,002 & $2 \times 10^{-5}$ & $\mathrm{HCO}_{3}-\mathrm{Mg}-\mathrm{Ca}$ \\
\hline BM-7610 & from spring & 0,4 & 7,5 & 0,026 & 0,005 & 0,06 & 0,03 & 0,09 & 0,05 & 0,18 & - & 0,002 & $4 \times 10^{-5}$ & $\mathrm{HCO}_{3}-\mathrm{Cl}-\mathrm{Ca}-\mathrm{M}$ \\
\hline Tr-505в & $103-159$ & 0,3 & 6,9 & 0,001 & 0,001 & 0,04 & 0,02 & 0,002 & 0,01 & 0,22 & - & 0,002 & $2 \times 10^{-5}$ & $\mathrm{HCO}_{3}-\mathrm{Ca}-\mathrm{Mg}$ \\
\hline KM-401в & $176-187$ & 0,3 & 7,1 & 0,001 & 0,001 & 0,04 & 0,02 & 0,004 & 0,002 & 0,24 & - & 0,001 & $1 \times 10^{-5}$ & $\mathrm{HCO}_{3}-\mathrm{Ca}-\mathrm{Mg}$ \\
\hline 459 & from spring & 1,2 & 7,1 & 0,03 & - & 0,21 & 0,07 & 0,02 & 0,63 & 0,26 & - & - & - & $\mathrm{SO}_{4}-\mathrm{Ca}-\mathrm{Mg}$ \\
\hline Osk-2a & $135-171$ & 5,3 & 6,9 & 1,87 & - & 0,09 & 0,03 & 2,84 & 0,20 & 0,23 & - & - & - & $\mathrm{Cl}-\mathrm{Na}$ \\
\hline $\mathrm{Km}-9$ & from spring & 23 & 7,5 & 7,44 & 0,12 & 1,03 & 0,19 & 11,9 & 2,50 & 0,14 & 0,01 & 0,02 & $4 \times 10^{-4}$ & $\mathrm{Cl}-\mathrm{Na}$ \\
\hline Km-BM-150 & from spring & 25 & 6,9 & 8,67 & 0,12 & 0,39 & 0,21 & 13,2 & 1,82 & 0,20 & 0,01 & 0,02 & $4 \times 10^{-4}$ & $\mathrm{Cl}-\mathrm{Na}$ \\
\hline Km-BM150A & from spring & 53 & 7,5 & 18,9 & 0,18 & 1,28 & 0,09 & 29,2 & 3,31 & 0,05 & 0,02 & 0,28 & $5 \times 10^{-4}$ & $\mathrm{Cl}-\mathrm{Na}$ \\
\hline Km-BM8007 & from spring & 114 & 7,3 & 41,6 & - & 1,69 & 0,26 & 67,7 & 2,04 & 0,08 & 0,25 & - & - & Cl-Na \\
\hline BM-113 & from spring & 131 & 7,9 & 49,0 & 0,56 & 1,29 & 0,22 & 76,9 & 3,03 & 0,12 & 0,04 & 0,04 & $2 \times 10^{-3}$ & $\mathrm{Cl}-\mathrm{Na}$ \\
\hline $\mathrm{Km}-9$ & 40 & 46 & 7,5 & 15,1 & 0,27 & 1,63 & 0,47 & 25,2 & 3,13 & 0,08 & 0,02 & 0,04 & $1 \times 10^{-3}$ & $\mathrm{Cl}-\mathrm{Na}$ \\
\hline Osk-1в & $22-50$ & 68 & 7,6 & 23,5 & 0,31 & 0,02 & 0,62 & 39,2 & 2,46 & 0,08 & 0,04 & 0,01 & $1 \times 10^{-3}$ & $\mathrm{Cl}-\mathrm{Na}$ \\
\hline Bk-1 & $115-118$ & 30 & 7,6 & 10,4 & - & 1,18 & 0,12 & 17,3 & 0,29 & 0,13 & 0,08 & - & - & $\mathrm{Cl}-\mathrm{Na}$ \\
\hline $\mathrm{Km}-12$ & 228 & 96 & 7,5 & 35,0 & 0,20 & 0,17 & 1,15 & 54,2 & 4,76 & 0,05 & 0,05 & 0,02 & $1 \times 10^{-3}$ & $\mathrm{Cl}-\mathrm{Na}$ \\
\hline \multicolumn{15}{|c|}{ Salt-bearing hydrogeological formation } \\
\hline Brm-2 & $278-2820$ & 338 & 5,8 & 81,4 & 12,1 & 29,0 & 6,71 & 205,0 & 0,23 & 1,10 & 2,86 & - & - & $\mathrm{Cl}-\mathrm{Na}-\mathrm{Ca}$ \\
\hline NTg-1 & $781-831$ & 344 & 6,3 & 30,5 & 15,1 & 65,4 & 9,22 & 217,7 & 0,21 & 0,69 & 3,57 & 1,85 & 0,28 & $\mathrm{Cl}-\mathrm{Ca}$ \\
\hline $\mathrm{Km}-1$ & $979-1135$ & 267 & 5,9 & 60,8 & 1,90 & 31,0 & 5,91 & 166,7 & 0,03 & 0,71 & 2,33 & 1,00 & - & $\mathrm{Cl}-\mathrm{Na}-\mathrm{Ca}$ \\
\hline Brm-1 & $1219-1279$ & 341 & 5,8 & 41,1 & 25,7 & 51,2 & 11,6 & 207,8 & 0,16 & 0,76 & 2,76 & - & - & Cl-Ca-Na \\
\hline Brm-1 & $1361-1374$ & 439 & 5,3 & 23,9 & 35,9 & 90,9 & 14,6 & 270,2 & 0,03 & 1,14 & 2,18 & - & - & $\mathrm{Cl}-\mathrm{Ca}$ \\
\hline $\mathrm{Km}-3$ & $1366-1443$ & 342 & 6,1 & 47,7 & 15,0 & 54,1 & 8,86 & 209,2 & 0,21 & 0,59 & 3,34 & 1,55 & 0,29 & $\mathrm{Cl}-\mathrm{Ca}-\mathrm{Na}$ \\
\hline Tg-1 & $1845-1875$ & 310 & 7,1 & 85,0 & 24,0 & 15,2 & 1,55 & 183,8 & 0,55 & - & 0,86 & 0,48 & - & $\mathrm{Cl}-\mathrm{Na}$ \\
\hline $\mathrm{Km}-5$ & $1890-1900$ & 230 & - & 32,0 & 11,5 & 47,0 & 3,80 & 147,3 & - & - & 2,95 & 1,40 & 0,05 & $\mathrm{Cl}-\mathrm{Ca}-\mathrm{Na}$ \\
\hline $\mathrm{Km}-5$ & $1890-1900$ & 329 & - & 43,0 & 17,0 & 68,0 & 8,50 & 209,7 & - & - & 2,95 & 2,20 & 0,07 & $\mathrm{Cl}-\mathrm{Ca}$ \\
\hline Md-156 & 1965-1977 & 405 & 6,5 & 29,9 & 14,5 & 90,0 & 11,2 & 251,2 & 0,16 & 1,46 & 6,44 & 2,44 & 0,26 & $\mathrm{Cl}-\mathrm{Ca}$ \\
\hline $\mathrm{Km}-4$ & $1990-2205$ & 380 & 6,1 & 49,7 & 19,0 & 68,5 & 8,63 & 237,5 & 0,18 & 0,84 & 4,83 & 2,68 & 0,12 & $\mathrm{Cl}-\mathrm{Ca}-\mathrm{Na}$ \\
\hline Yur-28 & $2090-2100$ & 298 & 5,7 & 49,8 & - & 48,4 & 8,99 & 188,2 & 0,55 & 0,70 & 2,51 & 0,82 & 0,05 & $\mathrm{Cl}-\mathrm{Ca}-\mathrm{Na}$ \\
\hline $\mathrm{Om}-1$ & $2235-2248$ & 147 & 4,9 & 30,9 & - & 22,1 & 1,91 & 91,6 & 0,57 & 0,18 & 1,96 & - & - & $\mathrm{Cl}-\mathrm{Na}-\mathrm{Ca}$ \\
\hline \multicolumn{15}{|c|}{ Subsalt hydrogeological formation } \\
\hline Yur-76 & $252-2530$ & 249 & 4,2 & 57,5 & 2,12 & 24,8 & 7,05 & 158,0 & 0,02 & - & 1,79 & 1,08 & 0,05 & $\mathrm{Cl}-\mathrm{Na}-\mathrm{Ca}$ \\
\hline Ol-152 & $2030-2248$ & 366 & 5,5 & 49,5 & 15,0 & 57,9 & 8,65 & 230,8 & 0,27 & 0,65 & 3,34 & 0,30 & 0,03 & $\mathrm{Cl}-\mathrm{Ca}-\mathrm{Na}$ \\
\hline Md-156 & $2136-2147$ & 240 & 2,3 & 17,9 & - & 50,4 & 13,1 & 155,0 & 0,58 & 0,00 & 3,33 & 1,04 & 0,01 & $\mathrm{Cl}-\mathrm{Ca}-\mathrm{Mg}$ \\
\hline $\mathrm{Km}-15$ & 2202 & 411 & 5,4 & 10,5 & 20,0 & 118 & 12,0 & 265,9 & 0,05 & 0,23 & 5,78 & 4,30 & 0,18 & $\mathrm{Cl}-\mathrm{Ca}$ \\
\hline En-154 & $2212-2271$ & 369 & 6,1 & 43,8 & 11,2 & 61,6 & 14,5 & 231,9 & 0,20 & 0,24 & 5,55 & 1,00 & 0,14 & $\mathrm{Cl}-\mathrm{Ca}-\mathrm{Na}$ \\
\hline Os-1 & $2235-2248$ & 150 & 6,7 & 31,3 & - & 22,1 & 1,90 & 91,6 & 0,57 & 0,11 & 1,96 & 0,53 & 0,03 & $\mathrm{Cl}-\mathrm{Na}-\mathrm{Ca}$ \\
\hline $\mathrm{Km}-9$ & $2228-2304$ & 214 & - & 41,4 & 3,70 & 29,1 & 4,74 & 132,2 & 0,001 & 0,06 & 2,36 & 1,19 & 0,03 & $\mathrm{Cl}-\mathrm{Na}-\mathrm{Ca}$ \\
\hline Yur-53 & $2298-2317$ & 255 & 5,2 & 58,4 & 5,06 & 24,0 & 6,38 & 160,1 & 0,09 & 0,24 & 1,10 & - & - & $\mathrm{Cl}-\mathrm{Na}-\mathrm{Ca}$ \\
\hline Yur-30 & $2318-2325$ & 242 & 5,5 & 37,3 & 3,63 & 21,6 & 14,8 & 141,0 & 0,91 & 0,51 & 2,88 & - & - & $\begin{array}{l}\mathrm{Cl}-\mathrm{Na}- \\
\mathrm{M}-\mathrm{C}-{ }^{2}\end{array}$ \\
\hline Yur -20 & 2314-2404 & 222 & 5,2 & 51,5 & - & 23,1 & 6,99 & 140,2 & 0,44 & 0,02 & 2,30 & 0,67 & 0,05 & $\mathrm{Cl}-\mathrm{Na}-\mathrm{Ca}$ \\
\hline Yur -19 & $2347-2375$ & 184 & 6,8 & 43,2 & - & 20,4 & 4,46 & 115,4 & 0,57 & 0,15 & 2,08 & 0,33 & 0,03 & $\mathrm{Cl}-\mathrm{Na}-\mathrm{Ca}$ \\
\hline Km-9 & $2353-2363$ & 226 & 5,0 & 42,8 & 4,10 & 32,0 & 5,50 & 140,7 & 0,001 & 0,31 & 2,69 & 1,32 & 0,04 & $\mathrm{Cl}-\mathrm{Na}-\mathrm{Ca}$ \\
\hline Yur -25 & $2372-2380$ & 184 & 6,0 & 38,3 & 3,25 & 13,6 & 9,97 & 112,9 & 0,41 & 0,31 & 5,65 & - & - & Cl-Na-Mg \\
\hline Yur -34 & $2374-2380$ & 168 & 4,8 & 27,8 & 2,75 & 14,2 & 12,7 & 106,4 & 1,35 & 0,10 & 2,11 & - & - & Cl-Na-Mg \\
\hline En-154 & $2378-2439$ & 315 & - & 52,1 & - & 54,0 & 7,50 & 195,8 & 1,05 & 0,21 & 4,56 & 1,56 & 0,10 & $\mathrm{Cl}-\mathrm{Ca}-\mathrm{Na}$ \\
\hline Yur -55 & 2394-2404 & 205 & 3,1 & 45,9 & 3,25 & 19,4 & 6,44 & 126,0 & 0,68 & 0,00 & 2,65 & 0,45 & 0,04 & $\mathrm{Cl}-\mathrm{Na}-\mathrm{Ca}$ \\
\hline Yur - 15 & $2418-2421$ & 217 & 5,1 & 47,5 & 5,00 & 21,2 & 6,20 & 133,4 & 0,51 & 0,06 & 0,70 & - & - & $\mathrm{Cl}-\mathrm{Na}-\mathrm{Ca}$ \\
\hline Yur -72 & $2446-2470$ & 240 & 6,3 & 57,2 & 4,57 & 22,8 & 5,37 & 147,4 & 0,41 & 0,55 & 1,27 & - & - & $\mathrm{Cl}-\mathrm{Na}-\mathrm{Ca}$ \\
\hline Yur -69 & $2454-2462$ & 231 & 4,2 & 48,3 & 4,00 & 18,0 & 12,2 & 146,0 & 0,92 & 0,18 & 1,68 & 0,43 & 0,03 & $\mathrm{Cl}-\mathrm{Na}$ \\
\hline Yur -106 & $2455-2464$ & 117 & 5,4 & 22,0 & 0,04 & 13,0 & 5,84 & 68,9 & 6,80 & 0,20 & 0,37 & - & - & $\mathrm{Cl}-\mathrm{Na}-\mathrm{Ca}$ \\
\hline $\mathrm{Km}-10$ & $2505-2569$ & 272 & 5,2 & 52,6 & 4,40 & 35,9 & 7,30 & 168,1 & 0,45 & 0,31 & 2,98 & 1,07 & 0,06 & $\mathrm{Cl}-\mathrm{Na}-\mathrm{Ca}$ \\
\hline Bk-1 & $2725-2813$ & 470 & 5,4 & 22,6 & 26,4 & 109 & 13,4 & 286,6 & 0,13 & 1,20 & 6,35 & 5,23 & 0,26 & $\mathrm{Cl}-\mathrm{Ca}$ \\
\hline
\end{tabular}

Salinity of brackish waters and brines varies from 1.2 to $131 \mathrm{~g} / \mathrm{L}$. Chlorine is a leading anion, with sodium to dominate among the cations. The content of calcium, magnesium and potassium is in the ratio $\mathrm{Ca}>\mathrm{Mg}>\mathrm{K}$ (rarely $\mathrm{Mg}>\mathrm{Ca}>\mathrm{K}$ ), with the maximum absolute value of these cations not to exceed $25 \%$-eq.

The $\mathrm{pH}$ is slightly changed from 6.9 to 7.9 .

Aquifer systems do not contain industrial concentrations of useful microcomponents. 
The underlying salt-bearing hydrogeological formation shows a stagnant hydrodynamic regime, high salinity (commonly, from 150 to $440 \mathrm{~g} / \mathrm{L}$ ), and highly metamorphosed chloride sodium-calcium, calcium-sodium and calcium (sometimes magnesium-calcium) composition of very strong brines. The salinity increases from the upper salt bearing formation to its bottom.

The maximum brine salinity of this formation indicates a high degree of their hydrodynamic isolation.

The anionic composition of the brines is extremely homogeneous, it is absolutely chloride. The percentage of chlorine is $98-100 \%$-eq. Sulfates and hydrocarbons are almost absent. The composition of the main cations is more different. More mineralized brines are calcium or calcium-sodium, less mineralized ones are often sodium-calcium and sodium brines. The $\mathrm{pH}$ value varies from 4.9 to 7.1 , with the environment, respectively, to be from acidic to neutral (Table).

In the upright section, as a rule, the brine-bearing horizons of the upper part of the Usolskaya and lower parts of the Belskian sequence have sharply increased salinity, which is determined by their position between the two main salt accumulation levels corresponding to the maximum salinity of the sedimentary basins. The increase of brine salinity is accompanied by an increase of not only calcium (50-75\%-eq.) and magnesium (7-14 \%-eq.), but also by other components. The concentration of bromine is $2.0-6.4 \mathrm{~g} / \mathrm{L}$, potassium 11.5-35.9 g/L, strontium 0.5-2.4 g/L. As in weak brines, iodine, silica, aluminum, iron, manganese, as well as other components occur.

The base subsalt hydrogeological formation is carbonate, terrigenous-sulfate-carbonate, terrigenous, and riphean regional brine bearing aquifer systems. Nearly everywhere, they contain strong, rarely very strong, chloride calcium-sodium and sodium-calcium brines.

In spite of the composition of the main components, the brines of the sub-salt formation have less salinity (gradually decreasing to $120-250 \mathrm{~g} / \mathrm{L}$ ) than the brines of the lower Cambrian formation. This is due to the difference in paleohydrogeological conditions and, above all, the lack of halogen formations in the Riphean and Vendian sediments, the initial brines of which were less mineralized than the Lower Cambrian ones. In the majority of samples of formation waters obtained from Riphean sediments, sodium predominates over calcium and magnesium ions, with its content to extremely rarely occur compared to the amount of calcium. Among anions chlorine prevails (as well as in the salt-bearing formation) (see Table).

The content of sulfates and hydrocarbonates in the region is insignificant. The acid-base parameters vary from 2.3 to 6.8 , i.e. in the subsalt hydrogeological formation there is water from strongly acidic to neutral (mostly it is slightly acidic).

\section{Conclusion}

The described geochemical properties of the groundwater of the YTHAZ determine the possibilities of their further practical use.

Aquifer systems of the upper part of the suprasalt formation comprise the vast majority of fresh water reserves of potable quality, which makes it possible to consider them as the main source of fresh-water of household and technical water supply. The geochemistry features of the salt-bearing formation demonstrate the sustainable isolation of water-bearing horizons and complexes, not only from infiltration waters, but also from each other. High water salinity does not allow us to use them for portable water system. To choose them for injection of produced water and industrial effluent makes the water-bearing horizons of this hydrogeological formation the most attractive.

The main objects of oil and gas production are connected with groundwater subsalt hydrogeological formations, so the water-bearing horizons and complexes can be of utmost 
interest as water sources for maintaining reservoir pressure, at any rate, they can also be used as objects for disposal of produced water and industrial waste.

The study area should also be noted to be characterized by high concentrations of useful components, and possess significant resources of such trace elements as lithium, bromine, strontium, boron, iodine, rubidium, and many others, that make them attractive for production of hydromineral raw material.

The reported study was funded by grants from RFBR according to the research project № 18-3500452 and the Russian Science Foundation (grant number № 17-17-01158).

\section{References}

1. D.A. Novikov, N.S. Trifonov, Arab J Geosci, 9, 63 (2016)

2. M.B. Bukaty, Russian Geology and Geophysics, 50, № 11, 930-942 (2009)

3. V.I. Vozhov Ground waters and hydromineral materials in the Lena-Tunguska hydrocarbon province (2006)

4. S.L. Shvartsev, Geochem. Int. 11, 1070-1083 (2000)

5. L.P. Alekseeva, S.V. Alekseev, Water resources, 45, 1 79-88 (2018)

6. K.J. Schulz, J.H. DeYoung Jr., R.R. Seal II, D.C. Bradley, Critical mineral resources of the United States-Economic and environmental geology and prospects for future supply (2017) 